\title{
Economics of $U$ sing Improved Firewood Cooking Stove and Its Contribution on Climate Change Adaptation and Mitigation
}

\author{
Zella Adili Y* and Sererya Ogossy G \\ Department of Economic Studies, The Mwalimu Nyerere Memorial Academy (MNMA)-Zanzibar, Tanzania
}

Submission: August 28, 2018; Published: September 21, 2018

*Corresponding author: Zella Adili Y, Department of Economic Studies, The Mwalimu Nyerere Memorial Academy (MNMA)-Zanzibar, P.0 Box 307, Zanzibar, Tanzania, Tel: +255 755 252238; Email: zellahadil@gmail.com

\section{Abstract}

This paper was an attempt to reveal the less known economics of using improved firewood cooking stove (ICS) and its contribution to climate change using Chamwino and Kilosa Districts, Tanzania as a case study. Data were collected through questionnaire survey and focus group discussions (FGD) to analyse variances between villages and in-depth testing of CCT to determine stove performance on emission level, time saving and firewood usage between ICS and the three stone cooking stove (3SF) in 120 households. Results revealed that ICS models save about $50 \%$ of firewood energy and $40 \%$ of cooking time, leading to $50 \%$ reduction in budget for firewood. Nevertheless, the use of ICS led to $65 \%$ reduction of GHGs emitted specifically $\mathrm{CO}$ and $\mathrm{PM}_{10}$ when cooking and $98 \%$ of the firewood collection time. High efficiency, especially in cooking time, was attributed to the two-pot design, energy conservation and high combustion efficiency by ICS.

Keywords: ICS: Improved Firewood Cooking Stove; Economics of ICS; Climate Change

\section{Introduction}

\section{Background Information}

Most people worldwide cannot access energy services that are based on efficient use of gaseous and liquid fuels, or electricity [1,2]. About $40 \%$ of the global population (almost three billion of people) relies on solid biomass-based fuels for their daily cooking purposes [3,4]. Biomass accounts for a significant proportion of total energy consumption: $60-95 \%$ in the poorest developing countries, $25-60 \%$ in middle-income countries, and $<5 \%$ in high-income industrialised countries [5].

In the field of energy, developing countries are faced with a two-edged sword; escalating prices for fossil fuels, and deforestation due to overexploitation of wood fuels [6]. In rural sub-Saharan Africa, virtually all households cook with biomass, mostly firewood [7]. The collection of and cooking with firewood is associated with various negative effects on the living conditions of the poor and the environment [8]. There is enormous potential for poor people in developing countries to switch to Liquefied Petroleum Gas (LPG,) and other modern fuels for cooking; exploiting that potential promises to improve the quality of their lives and bring major social, economic and environmental benefits - locally, regionally and globally. Around three billion people across the developing world still rely on solid fuels - traditional biomass (wood, charcoal, agricultural residues and animal waste) or coal - for cooking on primitive stoves or open fires [9]. In developing countries, communities living in remote areas have little or no access to more efficient, modern forms of energy which are environmentally friendly, economically viable and socially accepted, due to low income growth; they are relying on fuelwood that obtained from the natural forests freely sometimes cheaply as compared to the modern forms of energy [10].

Tanzanian households depend primarily on firewood as a source of energy whereby $64 \%$ out of 12.5 hectares of forest destructed every day is for firewood consumption [11]. Firewood consumption is the main cause of deforestation in Tanzania; it is responsible for degradation of $25 \%$ of closed woodlands and deforestation of $20 \%$ and $51 \%$ of closed and open woodlands respectively [12]. About $98 \%$ of households in the country rely on wood as a source of fuel for cooking [13]. Lusambo added that household wood-fuel consumption account to approximately $45 \%$ of total deforestation in Tanzania. In Tanzania, like many other sub-Saharan countries, communities use poor traditional cooking stoves technology for burning wood that results into adverse health, livelihoods, and local environment as well as climate change impacts generated by biomass burning during cooking and heating $[14,15]$. Women and their youngest children are the most directly affected and the main victims of illness and death due lack of access to the improved cook stoves (ICS) [16]. In South Africa alone, there are estimated cases of poisoning 
by gas emitted from poor designed technology cooking stoves, mostly affected are small children and women, resulting in 16 000 hospitalisations and 200 deaths annually [17].

\section{Problem Statement}

There is limited analysis that has been done for ICS benefits on economic, healthy and the environmental conservation [1822]. Capturing economic outcome of using improved firewood cooking stoves, users need to be aware on the performance of these stoves in terms of fuel consumption, burning rate, speed of cooking and level of toxic emitted [23]. This study provided detailed information on the usefulness of ICS to the community as well as its contribution to climate change adaptation with mitigation.

\section{Justification of the Study}

This study revealed detailed information concerning economic outcomes and the contribution of ICS to environmental conservation in the study area and to other areas that are facing serious deforestation and limited fuelwood problem. This is based on the reason that the use of improved firewood cooking stoves might be contributing much to the economic wellbeing of the community, through several ways including reduced firewood consumption, cooking time reduced and low pollutants emissions [24]. The findings from this study will be used by decision makers to suggest the best ways to reduce GHGs emission, fuelwood consumption and deforestation at community level as well as saving time and money.

\section{Objectives}

\section{Main Objective}

The main objective of this study was to assess economics of using improved firewood cooking stoves in Africa and its contribution to climate change mitigation using Chamwino and Kilosa districts, Tanzania as a case study.

\section{Specific Objectives}

The specific objectives of the study were to:

Examine the performance of the improved firewood cooking stoves in relation to the traditional three stone stoves in the study area.

Evaluate the economic outcomes of using improved firewood cooking stoves in the study area.

Analyse contribution of ICS in climate change mitigation in relation to the traditional three stone stoves in the study area.

\section{Methodology}

\section{Description of the Study Area}

The study was conducted in two districts, Chamwino in Dodoma and Kilosa in Morogoro. The criterion to choose Kilosa and Chamwino was that, currently there are two on-going projects on the "Improved firewood cooking stoves" and tree planting established by Trans-SEC project to reduce firewood pressure in the selected area of study. Dodoma Region is located at $6^{\circ} 10^{\prime} 23^{\prime \prime} S 35^{\circ} 44^{\prime} 31^{\prime \prime} \mathrm{E}$, in the centre of the country; it has seven districts including Chamwino District. Chamwino was selected due to the reason that, it is highly affected with the droughts as a result of deforestation, overgrazing and population growth as compared with other areas/districts in Dodoma [25]. Kilosa is located approximately $300 \mathrm{~km}$ inland from Dar es Salaam and about $139 \mathrm{~km}$ from Morogoro town. Kilosa covers an area of about 14, $245 \mathrm{~km} 2$. It is among the six districts making Morogoro region. Two villages were selected from each district, which are Idifu, Ilolo, Changarawe and Ilakala from Chamwino and Kilosa respectively.

Population: According to URT, Kilosa has about 438,175 people and out of that population, selected villages of Changarawe and Ilakala have population of 3,000 and 4100 people respectively according to the 2012 population census with average household size of 5 people. The villages cover land area of about 6000 and 4277 hectares respectively. Chamwino District has about 330,543 people, and out of that population, the villages of Idifu and Ilolo have a population of 5086 and 4,015 people with an average household size of 4 people [26].

Climate: Dodoma features a semi-arid climate with relatively warm temperatures throughout the year. While average highs are somewhat consistent throughout the year, average lows dip to $13^{\circ} \mathrm{C}\left(55.4^{\circ} \mathrm{F}\right)$ in July. Dodoma averages $570 \mathrm{~mm}$ of precipitation per year, the bulk of which occurs during its between November and April. Morogoro region lies in the south-eastern Tanzania between the central highlands and the coastal lowlands. The Region lies between latitude $5^{\circ} 58^{\prime \prime}$ and $10^{\circ} 0^{\prime \prime}$ to the South of the Equator and longitude $35^{\circ} 25^{\prime \prime}$ and $35^{\circ} 30^{\prime \prime}$ to the East. Kilosa has a tropical climate with the average temperature of $24.6^{\circ} \mathrm{C}$ and about $976 \mathrm{~mm}$ of rainfalls annually.

Economic Activities: More than $80 \%$ of the populations at Kilosa are farmers, whereby between those only $5 \%$ of that is farming in large scale farmers specialized in sisal which nowadays no longer practicable due to low market and high maintenance costs [27]. The main food crops grown include maize, rice, beans, cassava and banana. Cash crops grown are cashew nuts, sesame and sugarcane using poor technology with little or without agricultural inputs. The main economic activities done in Chamwino include the agriculture and pastorals mostly cattle and few goats and sheep. The cash crops grown include groundnuts, strawberry and sunflower using poor technology with no agricultural inputs [28].

\section{Research Design}

In this research, an experimental design basing on case study was used in studying the main economic outcome indicators including firewood consumption, time they are using in cooking, and level of emitted pollutants in the selected areas of the study as adapted [29]. A case study is a situation in real life that can be studied to learn about something. In the social sciences and life 
sciences, a case study is a research method involving an up-close, in-depth, and detailed examination of a subject of study, in a specific time and place. This case study is established under the financial support of two international research organizationsZALF and ICRAF, as among several households managed by these two organization. Each household has the ID number and name that differentiating one household from another, this case study is known as households of UPS No. 5 "Improved Cook Stoves", whereby in each District, two villages were chosen. Also, tree planting was established only at one village-Ilolo in Chamwino District as a pilot study to see how to improve the firewood supply and availability which will reduce the deforestation problem in future in areas where wood fuel is highly demanded.

The training that involved the identified households aimed to provide both theory and practical knowledge on ICS concerning construction process, requirements and materials, caring and maintenance as well stove evaluation processes by establishing monitoring sheets that will be used in collecting information on adoption of the stoves to the users who are members of the ICSs projects to all villages connected to the project and identifying the challenges on the construction of ICS in each selected village. Also, the training manual on ICS was prepared and distributed to each village involved in the study for further reference during indoor training of communities in their respective villages. A continuous evaluation and testing of the improved firewood cooking stove with a control test of three Stone fires was scheduled to access stove efficiency on time and firewood usage.

During training, the researcher demonstrated different local stoves used by community as an introduction, then introduced the recommended firewood improved cooking stove that technologically designed to reduce fuelwood consumption when cooking and heating. In each village, training started by identifying potential pioneers on the improved cook stoves and then forming sub-groups basing on hamlet which are closely neighboring for simplicity in communication and knowledge sharing (Plate 1).

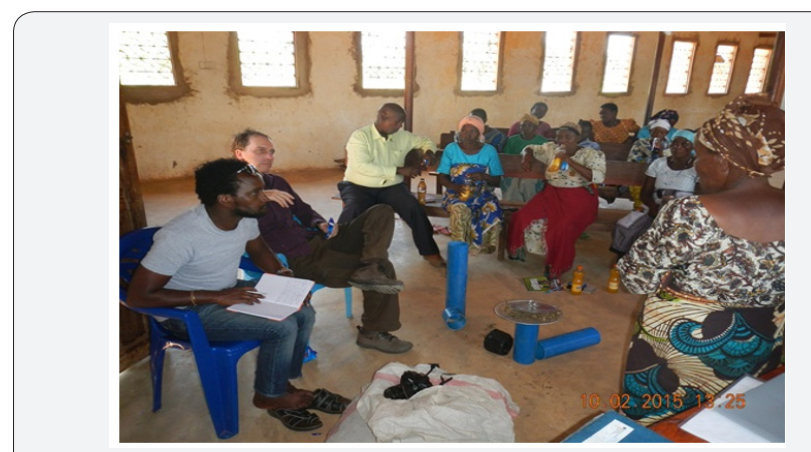

Plate 1: ICS members during training session at llolo villages, Chamwino.

All group members in each village were asked to prepare the material for the construction of improved firewood cooking stove as practical part of the training after theory session. The practical training continued as a stove building practice for extra three days. Stoves were built from mud mixed with dry chopped grass or groundnut husks and mud bricks. Other important equipment needed during the construction of these stoves is a tape measure for checking required measurements and five pieces of PVC-4 inches diameter pipes of different length sizes (Plate 2). The project succeeded to train adequate number of trainers that will be training other community members and improve the improved stoves step by step. A total of 98 qualified trainers were graduated for improved stoves construction. Among them, 23 villagers from Idifu, 25 villagers from Ilolo, 35 villagers from Changarawe and 15 villagers from Ilakala villages, making a total of 98 that we expect to keep training other community members on the construction and maintenance of improved cook stoves.

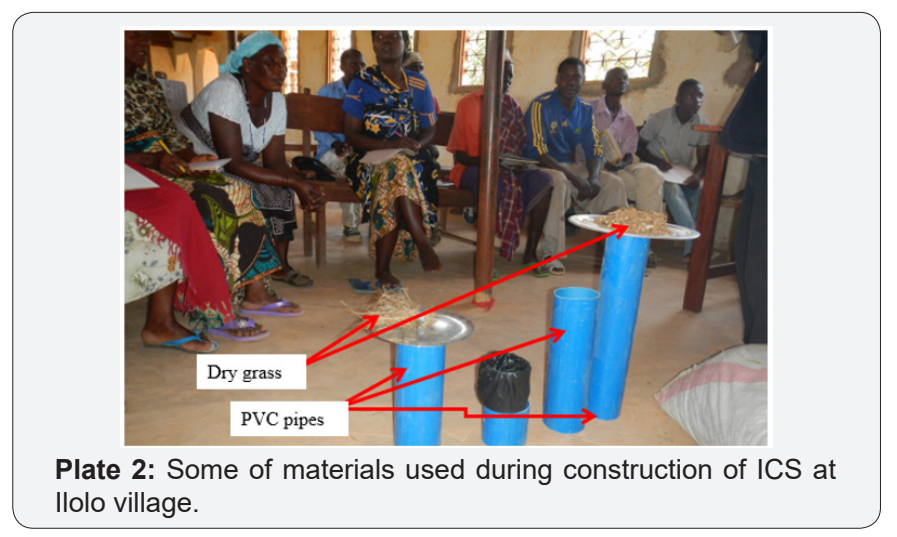

\section{Sampling Procedures and Sample Size Determination}

In this study, the sampling unit was a household, because household is among the basic unit of social analysis for scientific research. Purposively sampling was used to select districts and their respective villages for the study. The two districts selected were Chamwino and Kilosa in Dodoma and Morogoro regions respectively. Villages were purposively selected based on those only with ICS project implementation under the supervision of Tans-Sec (Germany) and ICRAF (Tanzania). According to Maas and Hox, the minimum sample size for social study is 30 households in each village was considered basing on the scarce resources, therefore a total of 120 households from households owning ICS were randomly selected from four (4) villages.

\section{Data Collection}

The survey methods that used in this study included households' questionnaire that captured household's characteristics and economic benefits of using the ICS technology. Also, scientific tests such as control cooking test (CCT) with field direct observation, Green House Gases (GHGs) emission and Dust - Total Suspended Particulates (TSP) test during cooking aimed in capturing stove efficiency using specialized equipment (KANE 900 and MicroDust Pro particulate sampler). Also, participatory rural appraisal with focus group discussion and documentary reviews were applied.

\section{Data Analysis}

Data collected under each measurement was compiled and analyzed with spreadsheet and SPSS software, which can analyze 
and illustrate the findings using different means like tables, charts and figures. Interpretation of the data utilized various standards and norms. Data was summarized, coded and entered into SPSS then analysed according the specific objectives.

Analysis on the Performance of ICS in Comparison with 3 SF: Specialized equipment such as KANE900 Gas Analyser and Particulate Matter Simpler was used to analyze types and level of gases and particulate matter emitted in percentage to both stoves (the 3 Stone fires and ICS) to compare their efficiency on the reduction of the gases emitted during cooking exercise. CCT measures the amount of fuel (g) or energy (KJ) transferred to the pot to cook $1 \mathrm{~g}$ of food (specific fuel consumption or specific energy consumption), and the time taken to cook the food. Results of CCT conducted in Kilosa and Chamwino are clearly comparing the 3 Stone fires and ICS using t-test. The specific fuel consumption (SCF) is calculated from the following relationships:

$$
\mathbb{C}_{F}=\frac{f_{d}}{W_{f}} * 1000
$$

Where fd is the mass of equivalent dry fuel used, in grams and $\mathrm{Wf}$ is the mass of food cooked in kg. A factor of 1000 in the formula is used to convert kilograms of fuel to grams. Cooking time (tc) is the duration from when the stove is ignited until when the food is cooked. All formulas used for calculations for other parameters and their description in CCT can be found at: http://www.pciaonline.org/node/1050 The data obtained were analyzed using Shell Foundation HEH CCT Excel Calculation Software Version 2.0 (http://www.pciaonline.org/node/1050).

Analysis on the Economic Implication of Adopting ICS Technology: All closed and open-ended responses to the questions were post-coded after being re-grouped into similar categories for analysis. Quantitative data was analysed using descriptive statistics and results on the household characteristics, firewood collection frequency, amount of usage in relation to the family size, were calculated and presented in tables, pie charts, mean, and graphs.

\section{Assumptions}

The average for one bundle head-load size is $25 \mathrm{~kg}$

The average price for one bundle of head-load size $25 \mathrm{~kg}$ is 3000 Tshs

The average price per one $\mathrm{kg}$ of firewood is $3000 / 25 \mathrm{~kg}=$ $120 /-$

Average household size is 5 members (Table 1)

Table 1: Per capita comparison of firewood consumption for ICS and 3SF.

\begin{tabular}{|c|c|c|c|}
\hline \multicolumn{2}{|c|}{ ICS technology } & \multicolumn{2}{c|}{ 3 SF technology } \\
\hline Family Size & $\begin{array}{c}\text { Firewood (Kg) used /Cooking } \\
\text { Session }\end{array}$ & Family Size & $\begin{array}{c}\text { Firewood (Kg) used /Cooking } \\
\text { Session }\end{array}$ \\
\hline 7 & 2470 & 7 & 4400 \\
\hline 9 & 2000 & 9 & 4900 \\
\hline 7 & 2000 & 8 & 4500 \\
\hline 8 & 2410 & 6 & 4300 \\
\hline 6 & 2600 & 3 & 1330 \\
\hline 3 & 880 & 2 & 1710 \\
\hline 2 & 870 & 4 & 3480 \\
\hline 4 & 400 & 3 & 2500 \\
\hline 3 & 1250 & 4 & 1220 \\
\hline 4 & 800 & 5.3 & 3234 \\
\hline Average 5.3 & 1568 & & 610 \\
\hline
\end{tabular}

Average per capita firewood consumption is $296 \mathrm{~g}$ for ICS and 610 for 3 SF (Table 2)

Table 2: Control Cooking Test on Percentage Improvement in Specific Fuel Consumption and Cooking Time results $(n=10)$.

\begin{tabular}{|c|c|c|c|c|}
\hline Stove Type & Comparable Variable & \% Difference & T-Test & Significant at P<0.05 \\
\hline 3-STONE vs. SALAMA & $\begin{array}{c}\text { Specific fuel consumption } \\
(\mathrm{kg} / \mathrm{kg})\end{array}$ & $34 \%$ & 5.3 & YES \\
\hline 3-STONE vs. SALAMA & Total cooking time (min) & $24 \%$ & 2.5 & YES \\
\hline
\end{tabular}

The Government average wage rate for 8 working hours a day in Tanzania

Average firewood collection time in Chamwino District is 8 hours; this is due to the long distance from the homestay.

245000 Tshs per Month as of 2015

The average wage per working hour $\{245000 /$ ( 8 hours x 26 working days)\} is 1178 Tshs
Average firewood collection time in Kilosa District is 3 hours; this is because the collection point is within one kilometre from homestay. 
SFC in gram per cooked $\mathrm{g}$ of food is $2.5 \mathrm{~g}$ on ICS and $7.5 \mathrm{~g}$ on $3 \mathrm{SF}$

$1000 \mathrm{~g}$ of food will consume $2500 \mathrm{~g}$ on ICS and $7500 \mathrm{~g}$ of firewood on $3 \mathrm{SF}$ respectively per cooking session.

The average cooking session for each $\mathrm{HH}$ is 3 times a day.

\section{Calculations}

\section{Firewood Consumption Per Day is:}

For ICS; $2500 \mathrm{~g}$ x $3=7500 \mathrm{~g}$ a day; per year is $7500 \times 30 \times 12$ $=2700000 \mathrm{~g} / 1000=2700 \mathrm{~kg}$

For $3 \mathrm{SF} ; 7500 \mathrm{~g} \mathrm{x} 3=22500 \mathrm{~g}$ a day; per year is $22500 \times 30$ $\mathrm{x} 12=8100000 \mathrm{~g} / 1000=8100 \mathrm{~kg}$

\section{NB: Saving is about $67 \%$ when using ICS}

Collection Time and Frequency: The collection frequency when using ICS is once per week; when using $3 \mathrm{SF}$ is twice a week. The collection time is different depending on the distance from home to collection point and firewood availability.

Average collection time;

$$
((8+3)) /(2=5.5)
$$

Frequency of collection: ICS - once per week; 3 SF twice per week

Time spent on firewood collection per year;

$(5.5 * 2) * 52$ weeks $=572$ hours When using $3 \mathrm{SF}$

$\left(5.5^{*} 1\right) * 52$ weeks $=286$ hours When using ICS

Collection time saved 286 hours, which is about $50 \%$ when using ICS

Then estimated money savings by converting time into money based on daily wage for the government rate and number of hours saved;

286hours*1178 Tshs= 336,908 Tshs When using ICS technology.

\section{Results and Discussions}

\section{Household Characteristics}

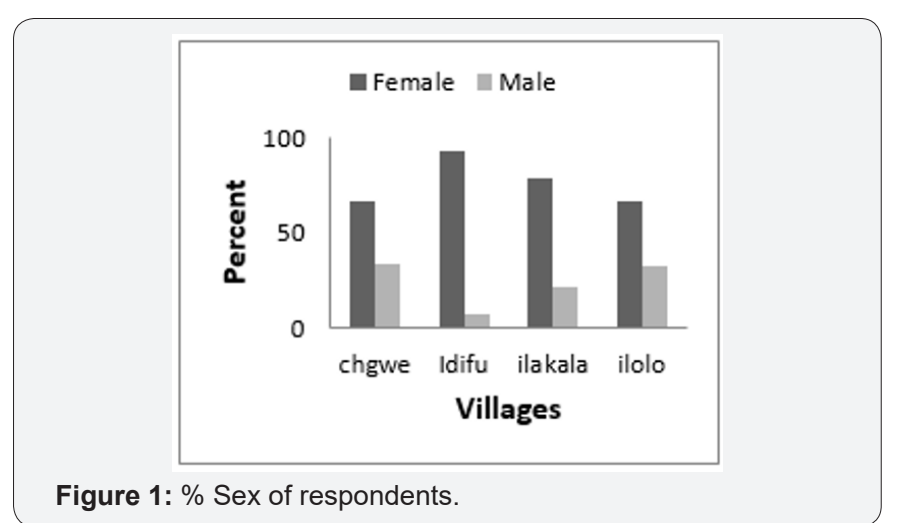

The results in Figure 1 revealed that about $78 \%$ of all respondents from all four villages were female as they are main cook in the respective households while the rest were males. It was observed that sometimes men do cook based on the situation whether single or a young man is responsible in a given household. This observation tallies. Traditionally, in most African societies men/husbands are normally the household head as observed in this study. For example, about $70 \%$ of the respondents declared men/husband to be a household head with the rest being on different status of whether a wife/women or brother/sister as head of the household (Figure 2). The mean household size obtained during this survey is 5 members per household (Figure 3). Farming was found to be major economic activity performed by most villagers. About $98 \%$ of respondents are pure farmers cultivating cash and food crops mainly sorghum, millet, maize, groundnuts and sunflower (Figure 4). There were different stoves in use in these sites, including the 3 Stone fires, charcoal stove, kerosene and the ICS. During the survey about $77 \%$ of the households were using only ICS technology, $13 \%$ of the ICS owners using also charcoal stove and only $10 \%$ of them are using traditional stove ( 3 stone fires).

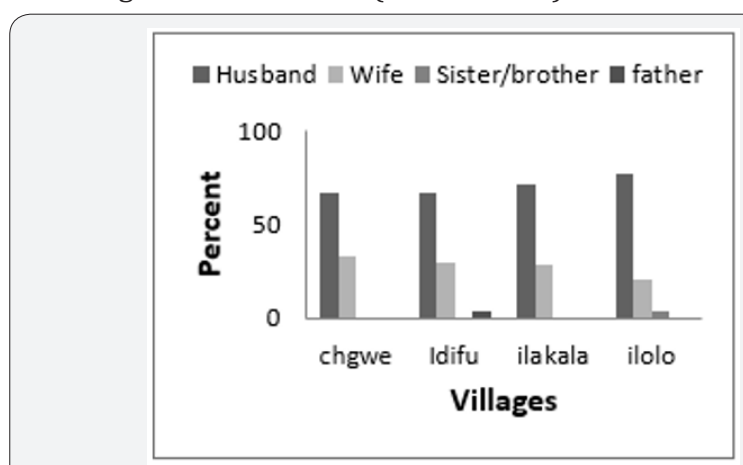

Figure 2: Percentage of head of the household.

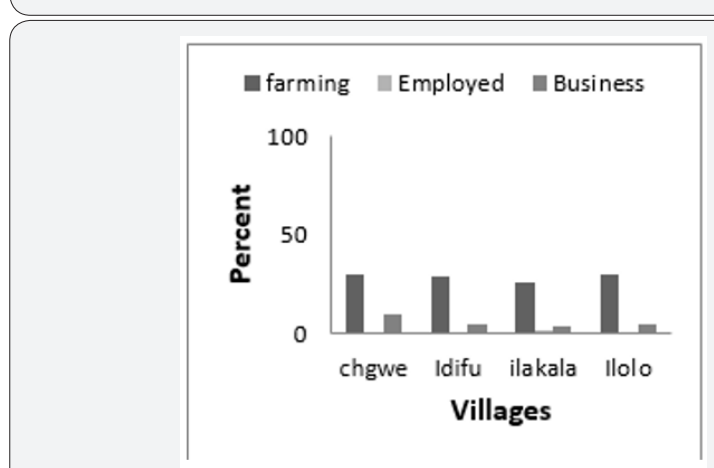

Figure 3: Frequently economic activities done at study areas.

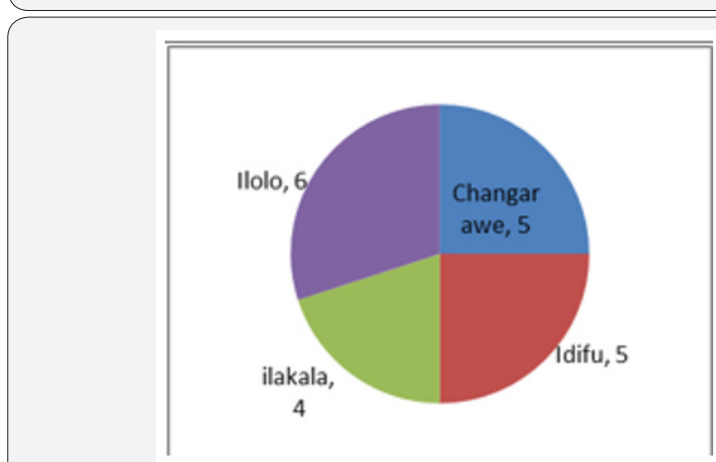

Figure 4: Household size. 


\section{The Efficiency of ICS in Relation to 3 SF}

Amount of Firewood Consumption: The results revealed that about $67 \%$ of the three stone fire users collect firewood twice a week. However, none of the ICS users collect at that frequency. It was found that all ICS users collect firewood only once a week (Figure 5). This is due to the fact that the consumption rate between the two stoves differs significantly. The ICS consumes little firewood as compared to 3 stone fires as it saves about $61 \%$ of the firewood consumed when using 3 Stone fires. Specific firewood consumption (SFC) results indicated that, the 3 stone stove has a higher specific fuel consumption of about 7.5g of firewood per 1 gram of food cooked compared to ICS which has only $2.3 \mathrm{~g}$ of firewood per 1 gram of the same food (Figure 6). These results suggest that ICS offered firewood savings of about $69 \%$ compared to the 3 Stone fires. Previous study noted a saving of 51.3 to $60 \%$.
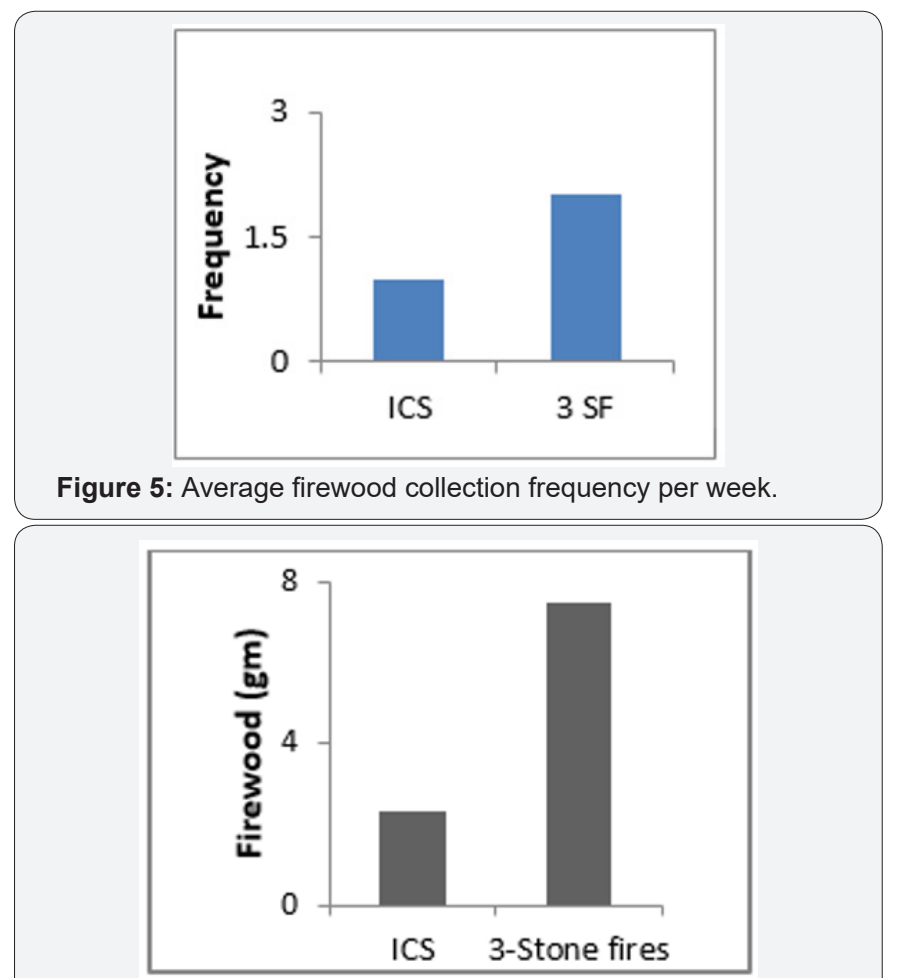

Figure 6: SFC (gram of firewood per $1 \mathrm{gm}$ of food cooked).

Lower saving of $32.1 \%$ has been reported by Fajola against 3 stone fires. However, the firewood consumption of the 3 Stone fires differs significantly indicating that ICS is effective in firewood consumption. Less firewood consumption by ICS could be due to one entrance for firewood and control air that increasing the burning rate as compared to 3 stone fires that has multiple unlimited entrances. Also, two potholes present in ICS allow the cook to operate two pots simultaneously using the same amount of firewood, as compared to the 3 Stone fires that allows the cooking to be done using one pot at a time. Also, the firewood chamber in the ICS controls the number of chopped pieces of firewood to be used at a time due to its specific diameter of $12 \mathrm{~cm}$. To the case of three Stone fires is different because of its design which allows multiple firewood entrance and is not designed to accommodate double potholes as in the ICS design (Plates 3 \& 4).

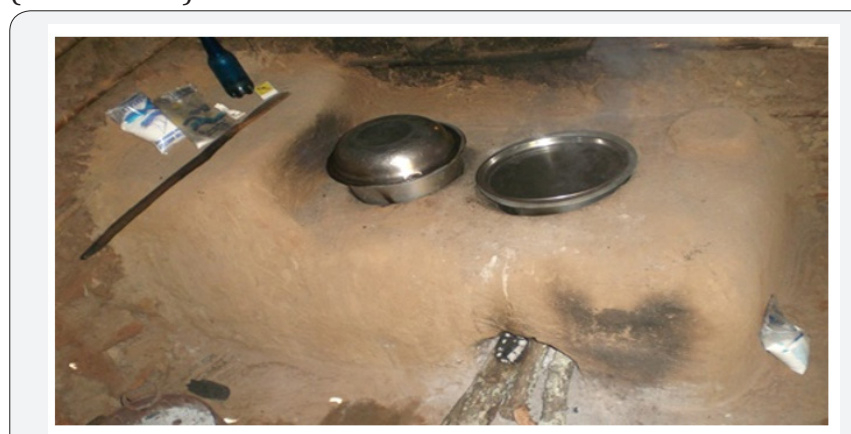

Plate 3: ICS; the technological design dictates efficiency on firewood usage.

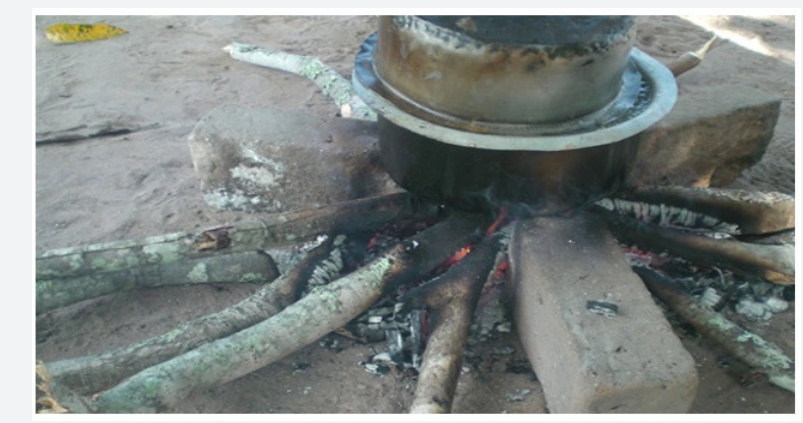

Plate 4: $3 \mathrm{SF}$; the technological design dictates efficiency on firewood usage.

Amount of Time Spent on Wood Collection: Firewood collection time in Chamwino was 420 minutes compared to 240 minutes in Kilosa. These results imply that communities in Chamwino travel longer distances to collect firewood possibly because of degradation of forests close to their settlement. Results show that ICS technology saves time during cooking which leads to low frequency of firewood collection (Figure 7). According to Malinski people that use 3 Stone fires have high frequency of collection due to the fact that traditional firewood stove consumes more amount of firewood during cooking and or heating. For example, results from Kilosa showed that people spend up to 3 hours for round trip of collecting firewood. The collection time saved by having ICS is about $50 \%$ which can be allocated to other socio-economic activities. In Chamwino, the collection point is far from settlement areas and this make some differences in time spent in firewood collection between these two.

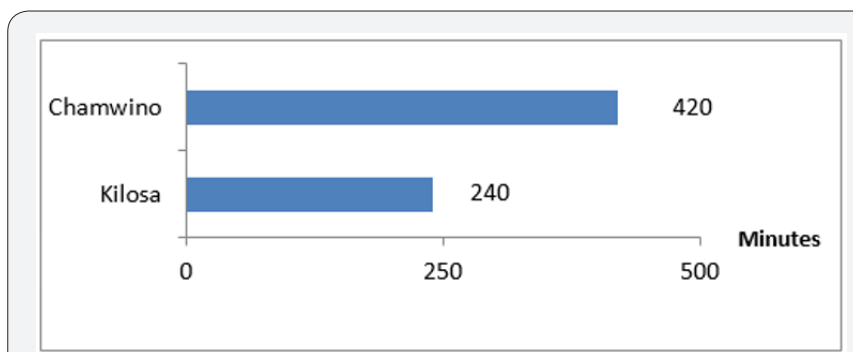

Figure 7: Time spent to collect Firewood depending on distance (in $\min$.). 


\section{International Journal of Environmental Sciences \& Natural Resources}

Effect of ICS on Cooking Time: CCT results revealed that ICS cooks faster by $24 \%$ and also reduces firewood consumption by $34 \%$ compared to 3 stone fires. The t-test statistics result also verifies that the differences in time and firewood consumption on ICS and that of 3 Stone fires is statistically different at $95 \%$ confidence interval (Table 2). ICS performed faster due to its design of having two potholes that allows the cook to operate with two pots simultaneously compared to 3 Stone fires that accommodate one pot at a time. Also, ICS provide full heat directly to the base of the pot with the help of the fire chamber that directing the flames to the pots without diverting as it experienced in the 3 Stone fires. Lastly, the maximum firewood combustion by ICS provide higher calories that contributes to the more heat that make it to do faster as to compare to the 3 Stone fires that has half firewood combustion (Plate 5).

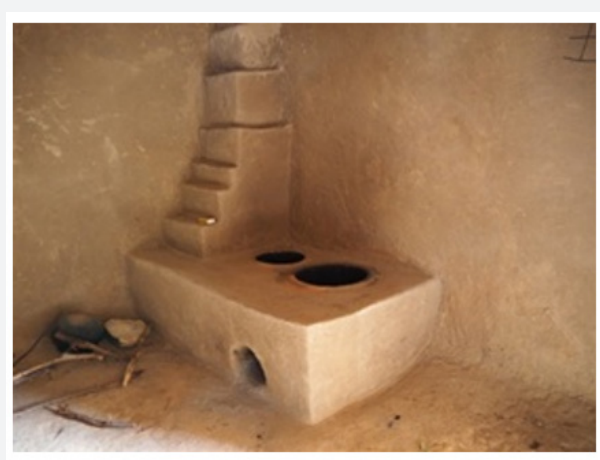

Plate 5: Technological design of ICS; two potholes, well controlled fire chamber.

Efficiency of ICS on GHGs: Generally, both stoves exhibited fewer emissions when cooking was done outside. This is because the produced emissions are quickly diluted with ambient air thus leaving less concentration around the stove vicinity. Findings on the emission study reported high average of $42.92 \mathrm{mg} / \mathrm{Nm} 3 \mathrm{CO}$ produced compared to $14.67 \mathrm{mg} / \mathrm{Nm} 3$ for the ICS. Compared to the performance of 3 stone fire, the GHG emission of ICS was lower, approximately 3 times less. Thus, by taking the 3 stone fires as a baseline emission value, the ICS reduces the CO emissions and their exposure by 74\% (Table 3 ). Another emission reported is carbon dioxide $\left(\mathrm{CO}_{2}\right)$. Emission level measured considered both when the stove was inside the kitchen and outside in the open environment. Though both stoves reduce emissions when cooking was done outside, the CO emissions from the ICS were even much lower, representing a reduction of $68.92 \%$ when the ICS was used as compared to the 3 stone fires. Similarly, when the stoves were inside, the emissions from 3 stone fires were $48.26 \mathrm{mg} / \mathrm{Nm} 3$, which is above the WHO CO standards of 35 $\mathrm{mg} / \mathrm{Nm} 3$ (WHO, 2010) as compared to that of the ICS of 18.84 $\mathrm{mg} / \mathrm{Nm} 3$. This represents a reduction of $60.95 \%$. The level of CO resulted by 3 stone fires is very high and due to this, traditional household energy practices ranked drastically consequences for health, the environment and socio-economic development, as it contributes to child pneumonia, chronic respiratory diseases, lung cancer in adults, adverse pregnancy outcomes and several other health outcomes.
Table 3: Carbon monoxide (CO) emissions summary.

\begin{tabular}{|c|c|}
\hline Stove Type and Configuration & $\mathrm{CO},(\mathrm{mg} / \mathrm{Nm} 3)$ \\
\hline \multicolumn{2}{|c|}{3 stone fires } \\
\hline $\begin{array}{c}\text { Average emissions (in and } \\
\text { outside) }\end{array}$ & 42.94 \\
\hline Average emissions inside & 48.26 \\
\hline Average emissions outside & 37.62 \\
\hline \multicolumn{2}{|l|}{ ICS (ICS) } \\
\hline $\begin{array}{c}\text { Average emissions (in and } \\
\text { outside) }\end{array}$ & 14.67 \\
\hline Average emissions inside & 18.84 \\
\hline Average emissions outside & 11.69 \\
\hline
\end{tabular}

Carbon Dioxide $\left(\mathrm{CO}_{2}\right)$ Emission: The results show that the overall average $\mathrm{CO}_{2}$ emissions, outside and inside included, for 3 stone fires is $0.04 \mathrm{mg} / \mathrm{Nm} 3$ whereas that for the ICS is 0.01 $\mathrm{mg} / \mathrm{Nm} 3$. Thus, the overall $\mathrm{CO}_{2}$ emissions reduction when ICS is used instead of 3 stone fires is $67.60 \%$ (Figure 8). The Figure shows that the ICS does perform better than the 3 stone fires in all the reported conditions. Both 3 stone fires and ICS performed better when the cooking was done outside rather than conducting cooking inside. The $\mathrm{CO}_{2}$ reduction of $47.73 \%$ (dropping from 0.05 to $0.03 \%$ ) was achieved when cooking with 3 stone fires outside compared to inside the kitchen. Similarly, the $\mathrm{CO}_{2}$ reduction for ICS was $57.51 \%$ as the emissions dropped from 0.03 to $0.01 \%$. When both 3 stone fires and ICS were used to cook outside, the $\mathrm{CO}_{2}$ emissions were comparatively fewer from the ICS. The emissions dropped from 0.03 to $0.01 \%$, which represents $\mathrm{CO}_{2}$ emission reduction of $69.83 \%$. On the other hand, when both stoves were inside, the emissions dropped from $0.05 \%$ (3 stone fires) to $0.02 \%$ (ICS), which represents a reduction of $62.88 \%$.

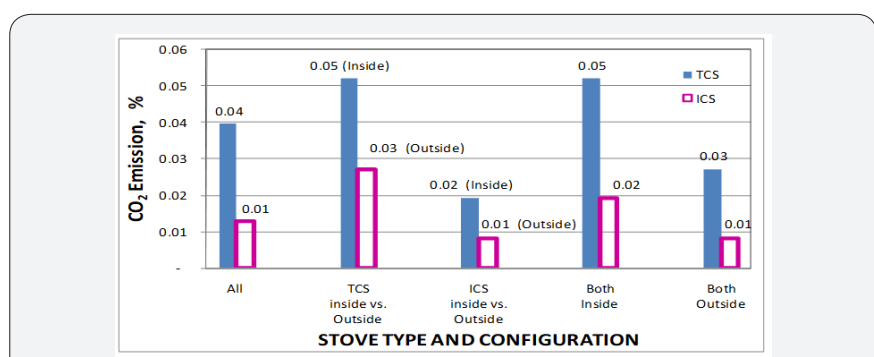

Figure 8: $\mathrm{CO}_{2}$ performance between 3 stone fires and ICS compared.

Total Suspended Particulates (TSP): The overall results on $\mathrm{PM}_{10}$ emissions assessment for the two types of stoves showed that the ICS was a better performer in all stove cooking configurations, outside and inside the kitchen. The average $\mathrm{PM}_{10}$ emissions to 3 stone fires were $0.0045 \mathrm{mg} / \mathrm{nm} 3$ whereas that for the ICS was $0.0020 \mathrm{mg} / \mathrm{nm} 3$. With these results, the average $\mathrm{PM}_{10}$ reduction by the ICS is $56.10 \%$ this result supported also by Fajola, Jetter and Miriam which their findings revealed the ICS to reduce to reduce dust by $32.1 \% 80 \%$ and $50 \%$ respectively against traditional stone fires (Figure 9). The differences between authors' results observed may be due to different study settings 
or environment e.g. ventilation in cooking environment. When both stoves were cooking inside, $\mathrm{PM}_{10}$ emissions to the 3 stone fires and ICS were 0.0060 and $0.0023 \mathrm{mg} / \mathrm{nm} 3$, respectively. Under these inside conditions, the ICS reduced $\mathrm{PM}_{10}$ emissions by $61.17 \%$ (Plates $6 \& 7$ ). Compared to inside condition, both stoves reduced the $\mathrm{PM}_{10}$ emissions when cooking was done outside. For the 3 stone fires, the emissions were reduced from 0.0060 to $0.0032 \mathrm{mg} / \mathrm{nm} 3$, which represent $47.30 \%$ emission reduction. Similarly, $\mathrm{PM}_{10}$ emissions for the ICS dropped from 0.0023 to $0.0017 \mathrm{mg} / \mathrm{nm} 3$, which is a reduction of $25.31 \%$. While outside and, in comparison to the 3 stone fires, the ICS reduced $\mathrm{PM}_{10}$ emissions by $44.96 \%$ as its emission was $0.0017 \mathrm{mg} / \mathrm{nm} 3$ compared to $0.0032 \mathrm{mg} / \mathrm{nm} 3$ for the 3 stone fires. Figure 9 show the comparative performance details of the $\mathrm{PM}_{10}$ emissions.

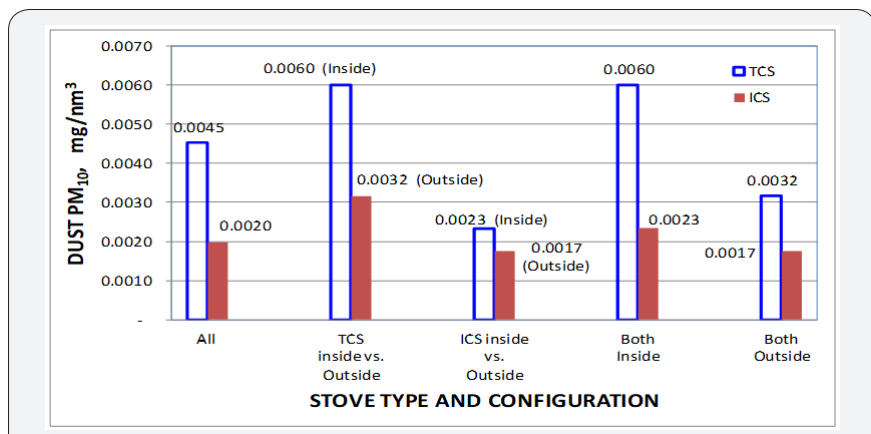

Figure 9: Dust $\mathrm{PM}_{10}$ emissions comparative performance between 3 stone fires and ICS.

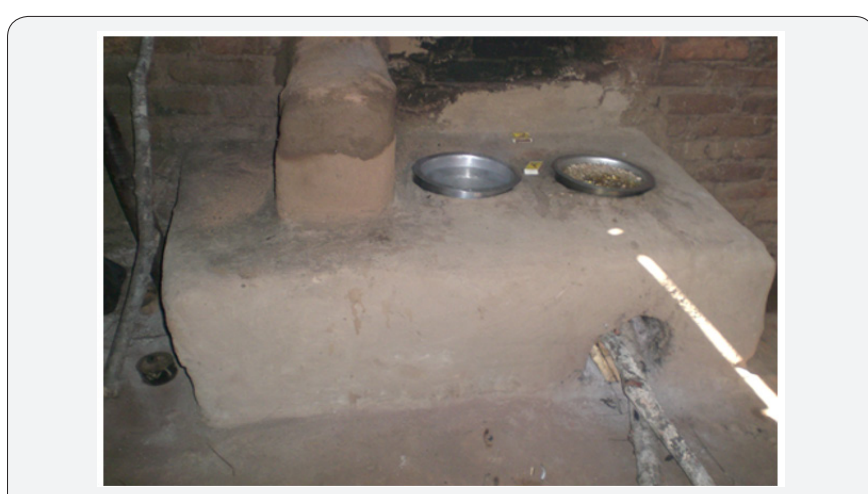

Plate 6: With ICS, smoke and dust are fully controlled and directed outside the kitchen environment through the chimney

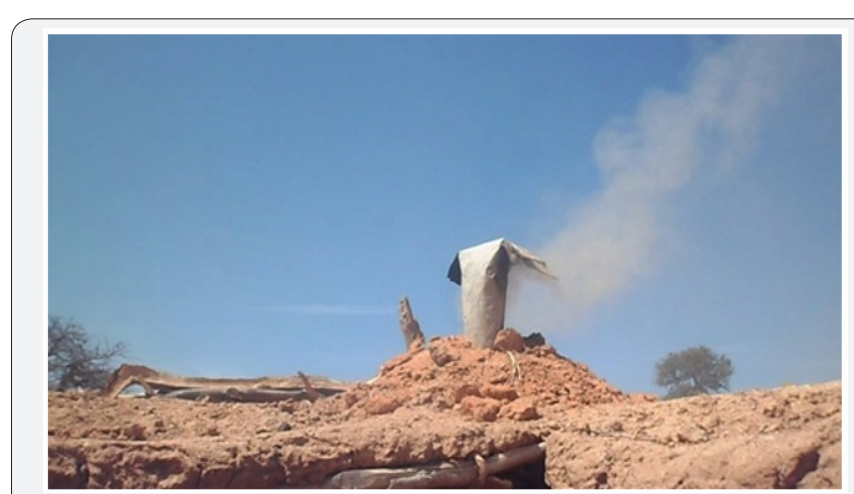

Plate 7: Smoke and dust from ICS are fully controlled and directed outside the kitchen environment through the chimney.

\section{Socio-Economic Implications of Using Improved Firewood Cooking Stoves}

Economic Activities: The study aimed to describe the economic implication of ICS to the peoples' livelihoods at the areas of interest. Some of economic activities done at the areas of study include farming, business and employed (Figure 4). ICS plays a major role in human health, environmental, economic, and social lives of families in developing countries. Some of the benefits described include reduction of indoor and outdoor air pollution by providing more complete combustion, whereby pollutants get outside the kitchen surroundings through the chimney, also it decreases burns by elevating the cooking surface off of the floor and the use of insulated materials on ICS construction. Due to ICS efficiency, households can easily improve economies and motivate users through excess time saved, dangers and drudgery as well as reducing unnecessary expenses involved during firewood collection, providing extra time for performing economic activities (Figure 10). Reducing firewood consumption can also help to improve soil fertility that will gear to more crops yields and also to reduce deforestation as the firewood demand will be highly minimized. Local economies benefit from fewer expenses on hospitalization due to harmful pollutants related diseases, burns, jobs creation associated with stoves building to new adopters and repair, and national economies from reduced respiratory associated illness, budget saving from environmental care and afforestation programme in deforested areas.

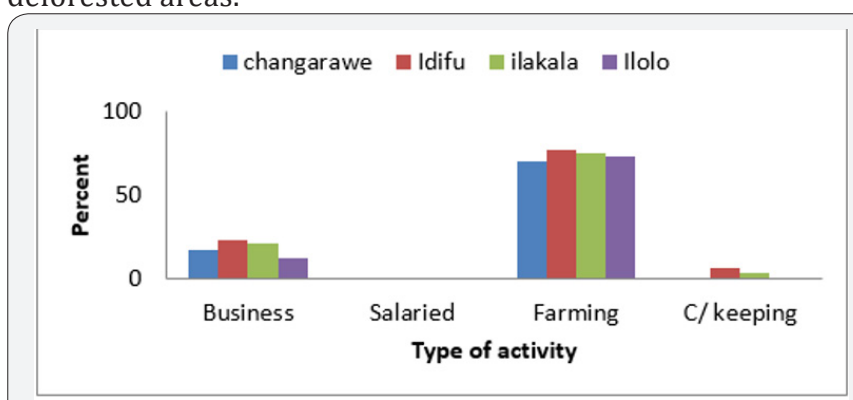

Figure 10: Economic activities done from time saved when using ICS as captured during household survey.

Amount of Money Spent on Firewood: The field observation revealed that amount of money households spent on firewood varies significantly due to the fact that some households only buy small amounts as a supplement to the collected firewood whereby others completely rely on bought firewood. The results revealed that, when using 3 stone fires spent more money on firewood of TZS 32,940 as to compare to when using ICS, which is TZS 15,984 . This dictates a saving of about $51.5 \%$ by using ICS which can be allocated to other necessary household's needs on daily life. This is because the ICS technology controls and maintains the combustion to the pot base and even cooking using two potholes simultaneously. The extra money saved from buying firewood when using ICS can be used to cover other expenses that are necessary including capitalizing more in farming activity for more yields (Figure 11). 


\section{International Journal of Environmental Sciences \& Natural Resources}

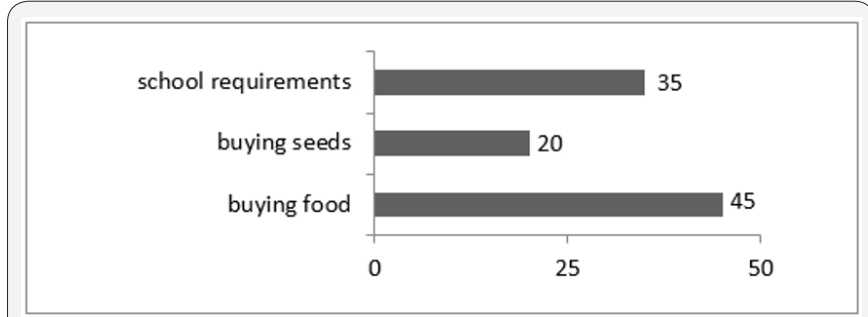

Figure 11: Extra expenditures (\%) covered with the saved money through firewood saving as captured during household survey.

ICS Technology as Source of Income: ICS technology is a source of income for stoves builders. Through a continuation of knowledge dissemination from village to village and even beyond new adopters is an opportunity for stove builders to get more income through building more stoves and get money for their daily expenditure (Figure 12) also during survey, about $97 \%$ of the respondents suggested that ICS is more effective on reducing harmful pollutants. Lusambo commented on the same rate of about $95 \%$ perfect on emission reduction of toxic gases, hence ICS is directly contributing to deduce unnecessary costs on checkup and treatment of respiratory illness resulted with toxic pollutants illness.

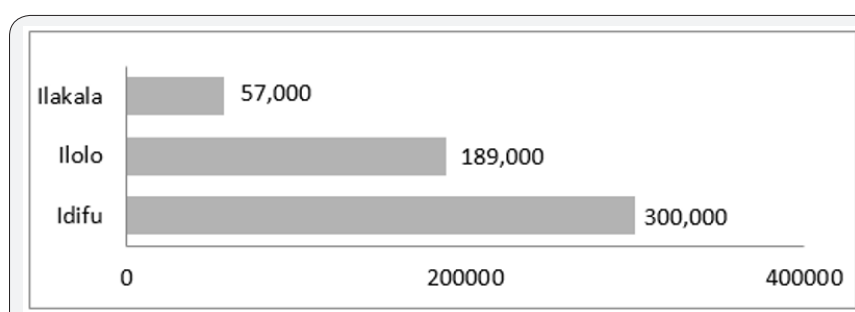

Figure 12: Income generated from ICS construction.

Table 4: Economic comparison of ICS technology and 3 SF to the community living at study sites.

\begin{tabular}{|c|c|c|c|c|}
\hline Parameter & ICS & $\mathbf{3 ~ S F}$ & $\begin{array}{c}\text { Saving } \\
\text { (\%) }\end{array}$ & $\begin{array}{c}\text { Money value } \\
\text { (Tshs) }\end{array}$ \\
\hline $\begin{array}{c}\text { FW } \\
\text { consumption/ } \\
\text { year }\end{array}$ & 2.7 (Tons) & 8.1 (tons) & $67 \%$ & 640000.00 \\
\hline $\begin{array}{c}\text { Collection } \\
\text { time/year }\end{array}$ & 286 hours & 572 hours & $50 \%$ & 336908.00 \\
\hline
\end{tabular}

Time and Firewood Saving: Calculated results indicates the firewood collection time saved of about 286 hours when using ICS technology compared to $3 \mathrm{SF}$, which is 572 hours per year. Then estimated money savings by converting the saved time into money based on daily wage for the government rate and number of hours saved is TZS 336,908 (Figure 13); therefore, the ICS technology revealed high economic importance to the community living at study sites and to the country as a whole by saving about $50 \%$ of the time and $67 \%$ of firewood consumption annually (Table 4). This result supported by other findings from several studies such as Nahayo who proved that adopting improved firewood stove results in high cost reduction rate of $50.33 \%$ compared to the traditional stove, Holmes found that
ICS reduces firewood consumption by $50 \%$ and Harerimana who obtained $51.35 \%$ reduction when using ICS technology.

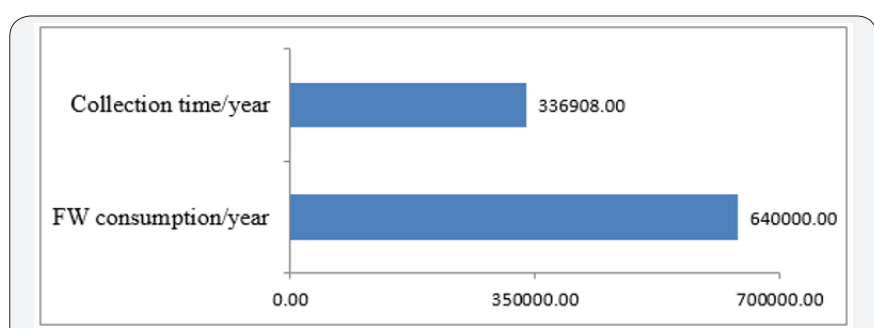

Figure 13: Saving in money value (Tshs).

\section{Conclusion}

Technological design of ICS favours the users due to its limited firewood chamber that allows a maximum of 2 to 3 pieces of wood at a time, also it has the two potholes that allow the user to cook and control two pots simultaneously. ICS has a well-designed fire chamber that provides maximum combustion and due to this, there is few firewood consumed and low level of emission. Apart from that, also the ICS is improvised with chimney that took smoke away the kitchen surroundings and therefore highly reduce the level of different harmful gases emitted during cooking. All the above make ICS to be more efficiency on consumption of firewood and fast cooking. The own and use of ICS technology reduce unnecessary costs on amount of firewood needed per day per household, and also for those buying firewood the saved money can be spent on other essential household requirements such as covering school fees, buying medicines and adding nutritive ingredients to households' daily meals. ICS technology is a source of employment especially to those stove builders and brick makers as they will be paid and selling bricks to those stove adopters respectively. Also, because the ICS has special chimney that take away the emitted gases during cooking, this reduces chances of suffering from respiratory related diseases and finally low costs on household's health cares. Therefore, this technology is economically viable to the community and to the country as a whole.

\section{Recommendations}

Since the use of the ICS technology significantly reduced harmful gases emitted during cooking, this indicates the economic efficiency of the technology and the viability to the environmental sustainability. The responsible key stakeholders including environmentalists, health workers and development specialists has to combine their efforts on promoting and implementation of ICS technology as it is socially acceptable to do away with - traditional stove with their adverse health, economic and environmental effects.

\section{References}

1. Belward A (2011) Renewable Energies in Africa, JRC Scientific and Technical Reports, European Commission Joint Research Center, Italy.

2. Clough L (2012) The Improved cook stove Sector in East Africa: Experience from Developing Energy Enterprise Programme (DEEP). 
3. Eleri A, Eleri EO (2009) Rethinking Biomass Energy in Sub Sahara Africa, Prospects for Africa Europe's Policies, VENRO (Association of German Development NGOs), German NGO Forum on Environment and Development and ICEED (International Centre for Energy, Environment and Development) Bonn, p. 20.

4. Habermehl H (2007) Economic Evaluation of the Improved Household Cookstoves Dissemination Programme in Uganda GTZ, Household Energy Programme HERA.

5. Harerimana J (2010) A contribution study on improved stove to reduce deforestation and increase household's saving: Higher Institute of Agriculture and Animal Husbandry (ISAE) p. 27-30.

6. Hazra S, Jessica Lewis I, Das Ashok KS (2014) Adoption and Use of Improved Stoves and Biogas Plants in Rural India Working Paper p. 86-14.

7. Holmes MS (2010) Potential Effects of Improved Cookstove Use and Barriers to Acceptance: A Case Study Measkron, Tanzania: United Nations Development Programme.

8. Jeuland MA, Pattanayak SK (2012) Benefits and Costs of Improved Cook Stoves: Assessing the Implications of Variability in Health, Forest and Climatic Impacts. PloS one 7: e30338.

9. Kahimba FC, Mbaga S, Mkoko B, Swai E, Kimaro AA, et al. (2015) Rainfed crop, livestock, and agroforestry systems in Semiarid and sub humid Tanzania: A Baseline report.

10. Kammen DM (2011) Household Cook-stoves, Environment, Health, and Climate Change: A New Look at an Old Problem. The Environment Department (Climate Change), The World Bank.

11. Kothari CR (2004) Research Methodology and Techniques (2 $2^{\text {nd }}$ Edn.); New Age International Publishers, New Delhi, India.

12. Legros G, Havet I, Bruce N, Bonjour S (2009) The Energy Access Situation in Developing Countries: A Review Focusing on the Least Developed Countries and Sub Saharan Africa. New York, United Nations Development Programme and World Health Organisation.

13. Lusambo LP (2009) Economics of Household Energy in Miombo Woodlands of Eastern and Southern Tanzania. PhD Thesis: School of the Environment and Natural Resources University of Bangor LL 57 2UW. The United Kingdom.
14. Maas CJM, Hox JJ (2005) Sufficient Sample Sizes for Multilevel Modeling: Utrecht University, The Netherlands. Methodology 1(3): 86-92.

15. Malimbwi RE, Misana S, Monela GC, Jambiaya G, Nduwamungu J (2001) Charcoal Potential in Southern Africa (CHAPOSA) Final Report, p. 67.

16. Miriam Z, Rojas L, Blanco S, Serrano P, Cruz J (2007) The impact of improved wood burning stoves on fine particulate matter concentrations in rural Mexican homes 17(3): 224-232.

17. Mehta S, Shahpar C (2004) The health benefits of interventions to reduce indoor air pollution from solid fuel use: A cost effectiveness analysis, in Energy for Sustainable Development 8: 53-59.

18. Msabila DT, Nalaila SG (2013) Research Proposal and Dissertation Writing: Principles and Practice: Nyambari Nyangwine Publishers, Dar es Salaam Tanzania.

19. Smith KR (2006) Health impacts of household fuelwood use in developing countries. Unasylva 224 (57): 41-44.

20. Smoulders SL, Bretschger, Egli H (2011) Economic Growth and the Diffusion of Clean Technologies: Environmental and Resource Economics 49(1): 79-99.

21. Stanistreet D, Puzzolo E, Bruce N, Pope D, Rehfuess E (2014) Factors Influencing Household Uptake of Improved Solid Fuel Stoves in Low and Middle Income Countries: A Qualitative Systematic Review. International Journal of Environmental Research and Public Health Whelan Building, University of Liverpool, Liverpool L69 3GB, UK, 11(8): 8228-8250.

22. Steve P, Hendriksen G, Watkiss P, Savage M, Maclean A (2012) Assessing the Benefits of a Lower Carbon Development Pathway for Zanzibar Technical Report (Final Version) Study Advisory Committee, Zanzibar.

23. UNDP /WHO (2009) The Energy Access Situation in Developing Countries, UNDP/WHO, New York.

24. URT (2012) Population and housing census: Population Distribution by Administrative Areas.

25. United Republic of Tanzania (URT) (2003) The National Energy Policy, Ministry of Energy and Minerals.

Your next submission with Juniper Publishers will reach you the below assets

- Quality Editorial service

- Swift Peer Review

- Reprints availability

- E-prints Service

- Manuscript Podcast for convenient understanding

- Global attainment for your research

- Manuscript accessibility in different formats

( Pdf, E-pub, Full Text, Audio)

- Unceasing customer service

Track the below URL for one-step submission https://juniperpublishers.com/online-submission.php 